Pesq. Vet. Bras. 29(5):369-374, maio 2009

\title{
Virulence factors and antimicrobial resistance of Staphylococcus aureus isolated from bovine mastitis in Rio de Janeiro'
}

\author{
Shana M.O. Coelho², Elina Reinoso ${ }^{3}$, Ingrid A. Pereira², Lidiane C. Soares ${ }^{2}$, \\ Mirta Demo ${ }^{3}$, Cristina Bogni ${ }^{3}$ and Miliane M.S. Souza ${ }^{4 *}$
}

\begin{abstract}
Coelho S.M.O., Reinoso E., Pereira I.A., Soares L.C., Demo M., Bogni C \& Souza M.M.S. 2009. Virulence factors and antimicrobial resistance in Staphylococcus aureus isolated from bovine mastitis in Rio de Janeiro. Pesquisa Veterinária Brasileira 29(5):369-374. Departamento de Microbiologia e Imunologia Veterinária, Instituto de Veterinária, Universidade Federal Rural do Rio de Janeiro, Seropédica, RJ 23890-000, Brazil. E-mail: miliane@ufrrj.br

The study was conducted to characterize pheno-genotypically the virulence factors and resistance pattern of Staphylococcus aureus isolates from milk samples of cows with subclinical mastitis. All hemolytic isolates presented beta-hemolysin, and $38 \%$ of the nonhemolytic isolates were able to express hemolysins in the presence of a beta-hemolytic strain. The amplification of the coa-gene displayed four different size polymorphisms with about $400 \mathrm{bp}, 600 \mathrm{bp}, 700 \mathrm{bp}$ and $900 \mathrm{bp}$. The spaA gene that encodes the IgG-binding region of protein $A$ revealed sizes of $700 \mathrm{bp}$ and $900 \mathrm{bp}$. The amplification of region $\mathrm{X}$ from spaA yielded a single amplicon for each isolate with the prevalent amplicon size being of $180 \mathrm{bp}$. Amplification of sae gene yielded an amplicon size of $920 \mathrm{bp}$ in $71 \%$ of the isolates. Antibiotic resistance pattern revealed that $42 \% S$. aureus were susceptible to all antimicrobials tested. Seven different antibiotic patterns were observed. Our results indicated that $47 \%$ and $25 \%$ of $S$. aureus strains exhibited resistance to penicillin and oxacillin respectively. All oxacillin-resistant isolates were mecA-positive.
\end{abstract}

INDEX TERMS: Staphylococcus aureus, antimicrobial resistance, virulence factors.

RESUMO.- [Fatores de virulência e resistência antimicrobiana em Staphylococcus aureus isolados de mastite bovina no Rio de Janeiro.] O presente estudo foi conduzido com o objetivo de caracterizar feno-genotipicamente os fatores de virulência e perfil de resistência aos antibióticos de Staphylococcus aureus isolados de amostras de leite de vacas com mastite clínica e subclínica. Em todos os isolados hemolíticos foi detectada a presença de beta hemolisina e 38\% dos não-hemolíticos produziram hemoli-

\footnotetext{
${ }^{1}$ Received on October 21, 2008.

Accepted for publication on December 4, 2008.

2 Curso de Pós-Graduação em Ciências Veterinárias, UFRRJ.

${ }^{3}$ Departamento de Microbiología e Inmunología, Facultad de Ciencias Exactas, Físico-Químicas y Naturales, Universidad Nacional de Río Cuarto, Ruta Nac. 36, Km 601, Código Postal X5804BYA Río Cuarto, Córdoba, Argentina.

${ }^{4}$ Departamento de Microbiologia e Imunologia Veterinária, Instituto de Veterinária, Universidade Federal Rural do Rio de Janeiro (UFRRJ), Seropédica, RJ 23890-000, Brazil.. Corresponding author: miliane@ufrrj.br
}

sinas na presença de cepa beta-hemolítica. A amplificação do gene coa apresentou quatro tipos polimórficos distintos com aproximadamente $400 \mathrm{bp}, 600 \mathrm{bp}, 700 \mathrm{bp}$ e 900 bp. O gene spaA que codifica a região de ligação da proteína $A$ à IgG apresentou bandas de 700 bp e 900 bp. A amplificação do gene que codifica a região $X$ revelou um único amplicon para cada isolado sendo o tamanho prevalente o de $250 \mathrm{pb}$. A amplificação do gene sae resultou em amplicons com $920 \mathrm{pb}$ em $71 \%$ dos isolados. $\mathrm{O}$ teste de suscetibilidade antimicrobiana revelou que $42 \%$ dos $S$. aureus foram sensíveis a todos os antibióticos testados. Foram observados sete diferentes padrões de resistência. Os resultados indicaram que $47 \%$ e $25 \%$ dos isolados foram resistentes à penicilina e oxacilina, respectivamente. Todos os isolados resistentes à oxacilina foram positivos para o gene mecA.

TERMOS DE INDEXAÇÃO: Staphylococcus aureus, resistência antimicrobiana, fatores de virulência. 


\section{INTRODUCTION}

Staphylococcus aureus is recognized as a major pathogen that also causes subclinical intramammary infections in dairy cows leading to severe economic losses in industry worldwide (Godden et al. 2002). In Brazil, several studies report the recovery of this agent from mastitic milk samples from cows (Schocken-Iturrino et al. 1996, Lange et al. 1999, Reis et al. 2003, Zafalon et al. 2007). This bacterium produces a variety of exoproteins that contribute to its ability to colonize mammary gland (Salasia et al. 2004), with five of them being different membrane-damaging toxins, four hemolysins (alpha-, beta-, gamma-, and delta-hemolysin) and leucocidin. Beta and alpha hemolysins are the most important in pathogenesis of the intramamarian infections (Park et al. 2004). The beta-toxin is a $\mathrm{Mg}^{2+}$-dependent sphingomyelinase $\mathrm{C}$, which degrades sphingomyelin in the outer phospholipid layer of the membrane (Linehan et al. 2003).

Staphylococcal protein $A$ is a membrane-bound exoprotein characterized and well known for its ability to bind to the Fc region of immunoglobulins of most mammalian species (Alonso \& Dagget 2000). This protein is codified by the spaA gene with a polymorphic $(\mathrm{X})$ and a conserved region. The polymorphic region $X$ consists of a variable number of repeated 24 pairs of bases being located in a codificant region of cellular wall C-terminal extremity (Koreen et al. 2004).

Coagulase protein has the ability to turn fibrinogen into fibrin threads by a mechanism different from natural clotting (Palma et al. 1999). Coagulase has also been shown to be a virulence factor in intrammmary infection. This protein is codified by the gene coa that possesses a conserved and a repeated polymorphic region that can be used to measure relatedness among $S$. aureus isolates. This region consists of repeated short sequences of 81 pairs of bases that are changeable in number and sequence and a fixed sequence of 330 pairs of base (Shopsin et al. 2000, Reinoso et al. 2004).

Sae operon is a two-component signal transduction system in $S$. aureus that regulates the expression of many virulence factors at the transcriptional level (Novik et al. 2003). This operon activates the expression of several virulence factors, including serine proteases, nuclease, coagulase (encoded by coa), alpha hemolysin (hla) and fibronectin-binding protein $\mathrm{A}(f n b A)$. The absence of gene sae seems to lead á and â hemolisins, DNAse and coagulase reduction (Giraudo et al. 1999).

Besides virulence factors, the increased resistance of $S$. aureus isolated from mastitic cows to several antimicrobial agents has been reported (Gentilini et al. 2000) what impacts the effectiveness of therapy since control methods of this organism from dairy herds requires treatment of infected mammary glands with effective antimicrobial agents (Kirkan et al 2005). The determination of antimicrobial susceptibility of clinical isolates is required not only for therapy but also for monitoring the spread of resistant strains throughout the populations. B-lactamic antibiotics are the most frequently used in intramammary infusion therapy. Bacterial resistance mechanisms to this class of antibiotics include production of B-lactamases and low-affinity penicillin-binding protein 2a (PBP2a) determined by the presence of the chromosomal gene mecA. The latter, designated for methicillin resistance, precludes therapy with any of the currently available B-lactam antibiotics, and may predict resistance to several classes of antibiotics (Moon et al. 2007). The isolation of $S$. aureus methicillin resistant (MRSA) from animals was first reported in 1972 following its detection in milk from mastitic cows (Devriese et al. 1972). Since then, reports have been published on MRSA infection in domestic animals, including dogs, cats, cattle, sheep, chickens, rabbits, and horses (Hartmann et al. 1997, Pak et al. 1999, Lee 2003, Goni et al. 2004). In recent years, the number of cases has shown an increasing trend (Rich \& Roberts 2004, O'Mahony et al. 2005, Weese et al. 2005).

The aim of the present study was to characterize pheno and genotipically Staphylococcus aureus strains isolated from subclinical mastitis in Rio de Janeiro, Brazil. To reach these objectives, and increase the range of information available about the genetic diversity of $S$. aureus isolated from cows with mastitis, what would allow to formulate strategies to reduce the spread of infection by this bacterium, hemolytic properties, coagulase (coa) and protein A ( $s p a)$ gene polymorphism, $S$. aureus exoprotein expression gene (sae), antibiotic resistance patterns and oxacillin resistance $(\operatorname{mec} A)$ were determined.

\section{MATERIALS AND METHODS}

Isolates. Milk samples were collected from 98 cows with subclinical mastitis. A total of 65 coagulase-positive Staphylococcus isolates was included in this investigation. Each one corresponding to a single animal.

Identification. The isolates were cultured in sheep blood agar and identified according to routine microbiological diagnostics, including cultural properties, catalase, coagulase, detection of hemolysis, maltose fermentation, acetoin production and nitrate reduction (Koneman 2008). The strains were further identified as $S$. aureus by PCR amplification of the 23S rDNA according Straub et al. (1999).

Phenotypic virulence factors. The production of hemolysins was also determined by cultivation of bacteria on sheep blood agar plates and in parallel by the interference of the hemolysins with the $\beta$-toxin of a $S$. aureus reference strain as described by Salka et al. (1979).

Antibiotic susceptibility. It was determined by the standardized agar diffusion test on MüllerHinton agar (Merck) using the following disks (Sensifar-Cefar): ampicillin (10mg), gentamicina (10mg) penicillin (10 IU), oxacillin (1 mg), vancomicyn (30mg) and ampicillin/sulbactam (10g). S. aureus ATCC 25923 was used as reference strain. Isolates were categorized as susceptible and resistant based upon interpretative criteria developed by the Clinical and Laboratory Standards Institute (CLSI) (2005).

Oxacillin susceptibility tests. It was included for detection of methicillin-resistant $S$. aureus. Resistance to methicillin was determined according to the test recommended by the CLSI, using an agar plate containing $6 \mathrm{mg} / \mathrm{ml}$ of oxacillin and Müller 
Hinton agar supplemented with $\mathrm{NaCl}(4 \% \mathrm{w} / \mathrm{v} ; 0.68 \mathrm{~mol} / \mathrm{L})$. Furthermore, oxacillin resistant strains were confirmed by PCR amplification of mecA gene (Coelho et al. 2007).

DNA extraction for PCR analysis. Staphylococcus aureus DNA was extracted from overnight cultures in $10 \mathrm{~mL}$ of brain heart infusion broth with slight modifications of the method reported by Senna et al. (2002). Briefly, bacterial cells were collected by centrifugation for $30 \mathrm{~s}$ at $14,000 \mathrm{rpm}$, washed in $1 \mathrm{~mL}$ of TE buffer (10mM Tris $\mathrm{HCl}, \mathrm{pH} 8.0 ; 1 \mathrm{mM}$ EDTA; $100 \mathrm{mM} \mathrm{NaCl})$, and recentrifuged. The pellet was resuspended in $400 \mu \mathrm{L}$ of TE buffer including $5 \mu \mathrm{L}$ of lysostaphin (stock concentration $1 \mu \mathrm{g} / \mathrm{mL}$; SigmaAldrich) and incubated for $30 \mathrm{~min}$ at $37^{\circ} \mathrm{C}$. Lysis was completed by the addition of $20 \mu \mathrm{L}$ of $10 \%$ SDS solution and incubation for $15 \mathrm{~min}$ at room temperature. DNA was then extracted with phenolchloroform-isoamylalchohol 25:24:1 and chloroformisoamylalchohol 24:1, respectively. The DNA was purified by ethanol precipitation and dissolved in a buffer containing10mM TrisClH(pH7.6) and 0.1mM EDTA (Reinoso, 2004).

PCR analysis. Polymerase chain reaction analysis of the coa, sae, spaA, rDNA and mecA genes were carried out using the primers and respective amplifications program described in Table 1. Reaction was performed in a final volume of $20 \mu \mathrm{L}$ of mixture containing PCR buffer (10mM TrisHCl, $\mathrm{pH}$ 9.0; $50 \mathrm{mM}$ $\mathrm{KCl}$, and $0.1 \%$ Triton X-100), $3.5 \mathrm{mM} \mathrm{MgCl}_{2}, 250 \mu \mathrm{M}$ of each of the deoxynucleoside triphosphates, 3.0 $\mu \mathrm{M}$ each gene-specific primers, $2.5 \mathrm{U}$ of Taq DNA Polymerase (Promega, Madison, $\mathrm{WI})$ and $5 \mu \mathrm{L}$ of template. The products of $10 \mu \mathrm{L}$ were analyzed by electrophoresis through a $1.0 \%$ agarose gel and pictures taken as described by Reinoso (2004).

\section{RESULTS AND DISCUSSION}

Among the 65 staphylococcal isolates from milk samples, 21 were identified as Staphylococcus aureus according to the results of phenotypical assays. These strains were confirmed by PCR amplification of the 23s DNA specific to $S$. aureus.

Nine isolates were hemolytic, with seven of them producing both alpha- and beta-hemolysis and two producing only beta-hemolysis. Interaction between alpha and beta toxins increases the adherence to bovine mammary epithelial cells and the proliferation of $S$. aureus (Cifrian et al. 1996). Furthermore, the capacity of the strains isolated from subclinical mastitis to produce both hemolysins indicates that these toxins might be necessary for the establishment of Staphylococcus strains in mammary glands as previously described by Cifrian et al. (1996) and Bownik \& Siwicki (2008).

Beta toxin hydrolyses the sphingomyelin present in the exoplasmic leaflet of the plasma membrane of most mammalian mammary glands cells, resulting in increased permeability with progressive loss of cell surface charge (Graves et al. 2007). Also, hydrolysis of sphingomyelin may render the cells more susceptible to the action of alpha toxin. In this study, beta hemolysin was present in all nine hemolytic isolates suggesting that this hemolysin may have an important role in mastitis pathogenesis (Park et al. 2004).

Twelve isolates were non-hemolytic. Five of these nonhemolytic isolates were able to express hemolysins in the presence of a beta-hemolytic strain. This phenomenon can probably be explained by the production of a deltahemolysin, whose expression depends on the presence of a beta-hemolytic isolate. Hemolytic synergism seems to be independent of hemolysin production, nevertheless, its action is considered as an enhancer to the colonization ability of Staphylococcus (Ali-Vehmas et al. 2001).

The $21 \mathrm{~S}$. aureus strains were additionally investigated for the presence of coa, spa and sae genes. All these genes displayed polymorphisms.

The amplification of the coa-gene displayed four different size polymorphisms with approximately 400 bp for one (4\%) strain, 600 bp for $12(57 \%)$ strains, 700 bp for $2(9 \%)$ strains and 900 bp for $6(28 \%)$ strains and based in these data the calculated number of repeats according to Hookey et al. (1998) were 1, 4, 5 and 7 repeats, respectively. These results are in agreement with the findings of Cabral et al. (2004) suggesting that an amplicon of about $600 \mathrm{bp}$ are predominant in bovine strains collected from Brazil. It is important to note that in the present study, some strains presented more than one amplicon what could be explained by the presence of more than one allelic form of the coagulase gene (Goh et al. 1992, Aslantas et al. 2007). In an

Table 1. Sequences of oligonucleotides primers with corresponding programs

\begin{tabular}{|c|c|c|c|}
\hline Gene & Primers $\left(5^{\prime}-3^{\prime}\right)$ & Program $^{a}$ & References \\
\hline 23S rDNA & $\begin{array}{l}\text { acg gag tta caa agg acg ac } \\
\text { agc tca gcc tta acg agt ac }\end{array}$ & 1 & Straub et al., 1999 \\
\hline $\begin{array}{c}\text { spaA } \\
\text { (X region) }\end{array}$ & $\begin{array}{l}\text { caa gca cca aaa gag gaa } \\
\text { ggc ttg ttg ttg tct tcc tc }\end{array}$ & 2 & Reinoso, 2001 \\
\hline $\begin{array}{c}\text { spaA } \\
\text { (lgG binding region) }\end{array}$ & $\begin{array}{l}\text { cac ctg ctg caa atg ctg cg } \\
\text { ggc ttg ttg ttg tct tcc tc }\end{array}$ & 2 & Reinoso, 2001 \\
\hline coa & $\begin{array}{l}\text { ata gag atg ctg gta cag g } \\
\text { gct tcc gat tgt tcg atg } c\end{array}$ & 3 & Reinoso, 2001 \\
\hline sae & $\begin{array}{l}\operatorname{tgc} \text { tgc tag ttt ctt tgg agc } \\
\text { att gat gag aag gat gcc ca }\end{array}$ & 4 & Giraudo et al. 1999 \\
\hline mecA & aaa atc gat ggt aaa ggt tgg $c$ & 6 & Coelho et al. 2007 \\
\hline
\end{tabular}

\footnotetext{
a $1=37 \times\left(94^{\circ} \mathrm{C}-40 \mathrm{~s}, 64^{\circ} \mathrm{C}-60 \mathrm{~s}, 72^{\circ} \mathrm{C}-75 \mathrm{~s}\right) ; 2=30 \times\left(94^{\circ} \mathrm{C}-60 \mathrm{~s}, 60^{\circ} \mathrm{C}-60 \mathrm{~s}, 72^{\circ} \mathrm{C}-60 \mathrm{~s}\right)$; $3=30 \times\left(4^{\circ} \mathrm{C}-60 \mathrm{~s}, 58^{\circ} \mathrm{C}-60 \mathrm{~s}, 72^{\circ} \mathrm{C}-60 \mathrm{~s}\right), 4=29 \times\left(93^{\circ} \mathrm{C} 1 \mathrm{~min}, 55^{\circ} \mathrm{C} 1 \mathrm{~min}, 72^{\circ} \mathrm{C} 1: 30\right.$ $\min ) ; 72^{\circ} \mathrm{C} 10 \mathrm{~min} ; 5=30 \times\left(94^{\circ} \mathrm{C}-60 \mathrm{~s}, 60^{\circ} \mathrm{C}-60 \mathrm{~s}, 72^{\circ} \mathrm{C}-60 \mathrm{~s}\right)$.
} 


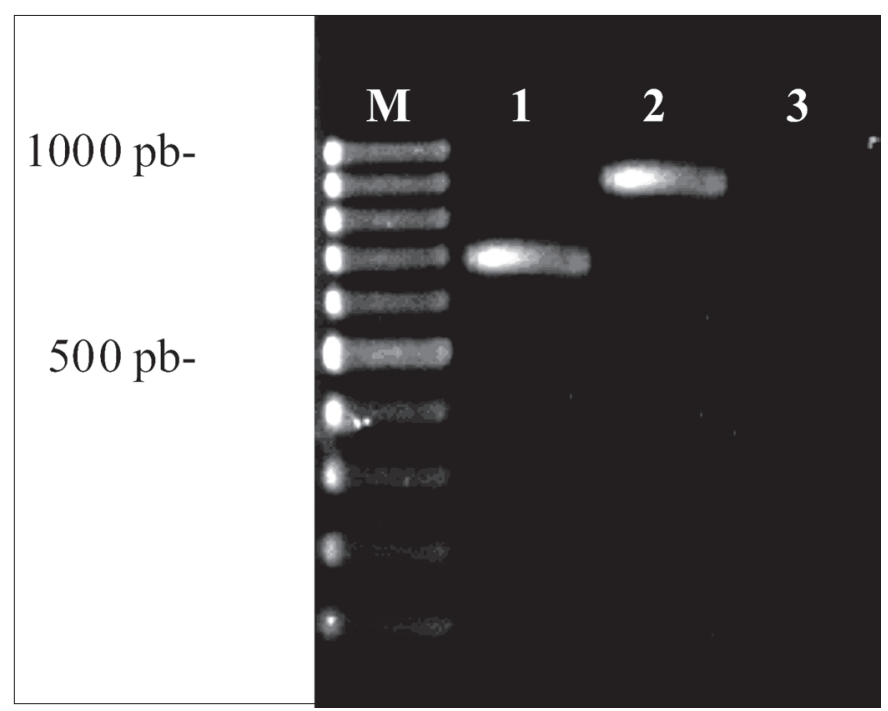

Fig.1. Agarose (1,5\%) gel electrophoresis of spaA Staphylococcus aureus PCR products. $M=100$ bp molecular weight standard, 1 = positive strain $(700 \mathrm{pb}), 2$ = positive strain (900pb), 3 = control reaction.

earlier study, performed in the south of Brazil, seven coa PCR types were observed, and 2 accounted for more than $50 \%$ of the isolates (Lange et al. 1999). Thus, in some Brazilian regions most cases of mastitis may be caused by $S$. aureus strains with the same coa genotype.

Protein A is a component of $S$. aureus cell wall and is covalently bound to the peptidoglycan. The PCR amplification of the gene encoding the IgG-binding region of protein A revealed bands of $700 \mathrm{bp}$ and $900 \mathrm{bp}$ (Fig.1). The amplification of region $\mathrm{X}$ from $s p a A$ yielded a single amplicon for each isolate with the prevalent amplicon size being of $250 \mathrm{bp}$ for 10 strains (38\%), $280 \mathrm{bp}$ for 9 strains $(14 \%)$ and $180 \mathrm{bp}$ for 8 strains (47\%). Frénay et al. (1996) affirmed that $s p a A$ gene above $260 \mathrm{bp}$ tends to be more related to epidemic than sporadic strains. The variability and stability of this gene indicate that sequence analysis of $s p a A$ gene could be use as an alternative system to the molecular typing of $S$. aureus isolates.

Amplification of sae gene yielded an amplicon size of $920 \mathrm{bp}$ for $15(71 \%)$ of the investigated S. aureus. According to the literature, this result could be explained by two possibilities, (1) either the gene sae is not present in all studied lineages (Reinoso, 2001) or (2) gene sae is polymorphic and is not always amplified by primers usage (Steinhuber et al. 2003, Goerke et al. 2005). From all saepositive isolates, ten showed no hemolytic profile and only four were alpha-beta hemolytic. Virulence gene expression in $S$. aureus is controlled by regulator genes like agr and sae. However, little information is available about the distribution of sae gene in $S$. aureus strains isolated from bovine and to our knowledge this is the first report that characterizes sae gene of $S$. aureus strains isolated from Brazil. Table 2 displayed these results plus the hemolytic properties, coa and spaA genes of the isolates.

Antibiotic resistance determination revealed that 9 isolates (42\%) were susceptible to all antimicrobials tested. Seven different antibiotic patterns were observed (Table 3). Twelve $S$. aureus isolates (57\%) were resistant to one or more than one antibiotic. Eight $(38 \%)$ isolates were resistant to three or more antibiotics. The predominant resistance pattern ampicillin/penicillin resistance was observed in 9 isolates (42\%), either alone or in combination

Table 2. Pheno and genotypic characteristics of Staphylococcus aureus strains

\begin{tabular}{|c|c|c|c|c|c|c|c|}
\hline \multirow[t]{2}{*}{ Strain } & \multirow[t]{2}{*}{ Hemolysis } & \multicolumn{2}{|c|}{ spaA gene (bp) } & \multirow{2}{*}{$\begin{array}{l}\text { No. of } \\
\text { repeats }\end{array}$} & \multirow{2}{*}{$\begin{array}{c}\text { coa gene } \\
\text { (bp) }\end{array}$} & \multirow{2}{*}{$\begin{array}{l}\text { No. of } \\
\text { repeats }\end{array}$} & \multirow{2}{*}{$\begin{array}{l}\text { sae } \\
\text { gene }\end{array}$} \\
\hline & & $\begin{array}{l}\text { IgG binding } \\
\text { Region }\end{array}$ & X Region & & & & \\
\hline SB 123 & $\mathrm{NH}^{\mathrm{a}}$ & 700 & 180 & 7 & 600 & 4 & + \\
\hline SB 124 & $\mathrm{NH}$ & 900 & 250 & 10 & 900 & 7 & + \\
\hline SB 125 & $\mathrm{NH}$ & 700 & 250 & 10 & 600 & 4 & - \\
\hline SB 126 & $\mathrm{NH}$ & 900 & 180 & 7 & 600 & 4 & + \\
\hline SB 127 & $\mathrm{NH}$ & 700 & 180 & 7 & 600 & 4 & - \\
\hline SB 128 & $b$ & 700 & 250 & 10 & 900 & 7 & + \\
\hline SB 129 & $\mathrm{NH}$ & 700 & 250 & 10 & 600 & 4 & $\mathrm{ND}^{\mathrm{b}}$ \\
\hline SB 130 & $\mathrm{NH}$ & 700 & 250 & 10 & 600 & 4 & + \\
\hline SB 131 & $\mathrm{NH}$ & 700 & 250 & 10 & 900 & 7 & + \\
\hline SB 132 & $\mathrm{NH}$ & 700 & 180 & 7 & 600 & 4 & + \\
\hline SB 133 & $\beta$ and $\alpha$ & 700 & 250 & 10 & 900 & 7 & + \\
\hline SB 134 & $\beta$ and $\alpha$ & 700 & 280 & 11 & 900 & 7 & + \\
\hline SB 135 & $\beta$ and $\alpha$ & 700 & 250 & 10 & 900 & 7 & - \\
\hline SB 136 & $\beta$ and $\alpha$ & 700 & 180 & 7 & 600 & 4 & + \\
\hline SB 137 & $\beta$ and $\alpha$ & 700 & 180 & 7 & 600 & 4 & + \\
\hline SB 138 & $\mathrm{NH}$ & 700 & 250 & 10 & 700 & 5 & + \\
\hline SB 139 & $\beta$ and $\alpha$ & 700 & 180 & 7 & 400 & 1 & - \\
\hline SB 140 & $\mathrm{NH}$ & 700 & 180 & 7 & 700 & 5 & + \\
\hline SB 141 & $\mathrm{NH}$ & 700 & 280 & 11 & 600 & 4 & + \\
\hline SB 142 & $\mathrm{NH}$ & 700 & 280 & 11 & 600 & 4 & + \\
\hline SB 143 & $\beta$ and $\alpha$ & 700 & 250 & 10 & 600 & 4 & - \\
\hline
\end{tabular}

$\overline{\mathrm{a}} \mathrm{NH}=$ non-hemolytic, ${ }^{\mathrm{b}} \mathrm{ND}=$ non-determined 
Table 3. Antibiotic resistance patterns of Staphylococcus aureus strains

\begin{tabular}{ccc}
\hline Pattern & Resistance phenotype & Number of strains \\
\hline 1 & Amp, Pen, Oxa, Van, Gen & 4 \\
2 & Amp, Pen, Oxa, Gen & 2 \\
3 & Amp, Pen,Gen & 2 \\
4 & Amp, Pen & 1 \\
5 & Pen, Gen & 1 \\
6 & Gen & 2 \\
7 & - & 9 \\
\hline
\end{tabular}

a Amp = ampicillin, Gen = gentamicin, Pen = penicillin, Oxa = oxacillin, Van = vancomicin .

with resistances to other antimicrobials and $47 \%$ of $S$. aureus strains exhibited resistance to penicillin and this widespread of resistance could be a consequence of the widespread application of B-lactamic antibiotics frequently used in intramammary infections in Brazil agreeing with the WHO report (2002) that suggest that overuse and misuse of antibacterial agent could be responsible as the major selective force leading to the development of bacterial resistance. Also, 6 strains $(25 \%)$ resistant to oxacillin and 4 strains $(17 \%)$ resistant to vancomicin were detected with the oxacillin resistance confirmed by mecA detection through PCR assay (Lee et al. 2004).

\section{CONCLUSIONS}

To our knowledge, this is the first report of sae gene in Staphylococcus aureus strains isolated from animal origin in Brazil.

The study of biological and molecular characteristics of these isolates demonstrated the presence of resistance to several antimicrobial agents and production of different virulence factors related to the pathogenesis of this agent.

Acknowledgments.- This study was partially supported by CAPESSECYT to Shana Mattos de Oliveira Coelho and FAPERJ (Proc.E-26/ 171.366/2006).

\section{REFERENCES}

Ali-Vehmas T., Vikerpuur M., Pyörälä S. \& Atroshi F. 2001 Characterization of hemolytic activity of Staphylococcus aureus strains isolated from bovine mastitic milk. Microbiol. Res. 155(4):339-344.

Alonso D.O.V. \& Daggett V. 2000. Staphylococcal Protein A: Unfolding pathways, unfolded states, and differences between the $B$ and $E$ domains. Proc. Natl Acad. Sci. USA 97:133-138.

Aslantas O., Demir C., Türütoglu H., Cantekin Z., Ergün Y. \& Dogruer G. 2007. Coagulase Gene polymorphism of Staphylococcus aureus isolated from subclinical bovine mastitis. Turk. J. Vet. Anim. Sci. 31(4):253-257.

Bownik A. \& Siwicki A.J. 2008. Review paper: Effects of staphylococcal hemolysins on the immune system of vertebrates. Centr. Eur. J. Immunol. 33(2):87-90.

Cabral K.G., Lammler C., Zschock M., Langoni H., De Sa Me, Victoria C. \& Da Silva A. 2004. Pheno- and genotyping of Staphylococcus aureus, isolated from bovine milk samples from Sao Paulo State, Brazil. Can. J. Microbiol. 50(11):901-909.

Cifrian E., Guidry A.J., Bramley A.J., Norcross N.L., Bastida-Corcuera F.D. \& Marquardt W.W. 1996. Effect of staphylococcal alpha toxins on the cytotoxicity, proliferation and adherence of Staphylococcus aureus to bovine mammary epithelial cells. Vet. Microbiol. 48:187-198.
Clinical and Laboratory Standards Institute 2005. Methods for dilution antimicrobial susceptibility tests for bacteria that grow aerobically: Approved standards. CLSI Document M45-P, Wayne, Pa..

Coelho S.M.O., Menezes R.A., Soares L.C., Pereira I.A., Gomes L.P. \& Souza M.M.S. 2007. Mapeamento do perfil de resistência e detecção do gene mecA em Staphylococcus aureus e Staphylococcus intermedius oxacilina-resistentes isolados de espécies humanas e animais. Ciência Rural 37(1):195-200.

Devriese L.A., Vandamme L.R. \& Fameree L. 1972. Methicillin (cloxacillin)-resistant Staphylococcus aureus strains isolated from bovine mastitis cases. Zbl. Vet. Med. B 19:598-605.

Frenay H., Bunschoten A., Schouls L., Van Leeuwen W., Vandenbroucke-Grauls C., Verhoef J. \& Mooi F. 1996. Molecular typing of methicillin-resistant Staphylococcus aureus on the basis of protein A gene polymorphism. Eur. J. Clin. Microbiol. Infect. Dis. 15:60-64.

Gentilini E., Denamiel G. \& Betancor A. 2002. Antimicrobial suscettibility of coagulase-negative stphylococci isolated from bovine mastitis in Argentina. J. Dairy Sci. 85:1913-1917.

Giraudo A., Calzolari A., Cataldi A.A., Bogni C. \& Nagel R. 1999. The sae locus of Staphylococcus aureus encodes a two-component regulatory system. FEMS Microbiol. Lett. 177:15-22.

Godden S.M., Jansen J.T., Leslie K.E., Smart N.L. \& Kelton D.F. 2002. The effect of sampling time and sample handling on the detection of Staphylococcus aureus in milk from quarters with subclinical mastitis. Can. Vet. J. 43:38-42.

Goerke C., Fluckiger U., Steinhuber A., Bisanzio V., Ulrich M., Bischoff M., Patti J.M. \& Wolz C. 2005. Role of Staphylococcus aureus Global Regulators sae and beta in Virulence Gene Expression during DeviceRelated Infection. Infection and Immunity 73(6):3415-3421.

Goh S.H., Byrne S.K., Zhang J.L. \& Chow A.W. 1992. Molecular typing of Staphylococcus aureus on the basis of coagulase gene polymorphisms. J. Clin. Microbiol. 30:1642-1645.

Goni P., Vergara-Ruiz J., Albizu I., Vila J.\& Gomez-Lus R. 2004. Antibiotic resistance and epidemiological typing of Staphylococcus aureus strains from ovine and rabbit mastitis. Int. J. Antimicrob. Agents 23:268-272.

Graves E.L.F., Beaulieu A.D. \& Drackley J.K 2007. Factors affecting the concentration of sphingomyelin in bovine milk. Dairy Sci. 90:706-715.

Hartmann F.A., Trostle S.S. \& Klohnen A.A. 1997. Isolation of methicillinresistant Staphylococcus aureus from a postoperative wound infection in a horse. J. Am. Vet. Med. Assoc. 211:590-592.

Hookey J.V., Richardson J.F. \& Cookson B.D. 1998. Molecular typing of Staphylococcus aureus based in PCR restriction fragment length polymorphism and DNA sequence analysis of the coagulase gene. J. Clin. Microbiol. 36(4):1083-1089.

Kirkan S., Goksoy E.O. \& Kaya O. 2005. Identification and Antimicrobial Susceptibility of Staphylococcus aureus and coagulase negative Staphylococci from bovine mastitis in the Aydin Region of Turkey. Turk J. Vet. Anim. Sci. 29:791-796.

Koneman E.W., Allen S.D., Janda W.M., Schreckenberger M.P.C. \& Winn Jr. W.C. 2001. Diagnóstico Microbiológico - Texto e Atlas Colorido, 5a ed. MEDSI, São Paulo.

Koreen L., Ramaswamy S.V., Graviss E.A., Naidich S., Musser J.M. \& Kreiswirth B.N. 2004. spa typing method for discriminating among Staphylococcus aureus isolates: implications for use of a single marker to detect genetic micro- and macrovariation. J. Clin. Microbiol. 42:792799.

Lange C., Cardoso M., Senczek D. \& Schwarz S. 1999. Molecular subtyping of Staphylococcus aureus isolates from cases of bovine mastitis in Brazil. Vet Microbiol. 67:127-141.

Lee J.H., Jeong J.M., Park Y.H., Choi S.S., Kim Y.H., Chae J.S., Moon J.S. \& Kim S. 2004. Evaluation of the methicillin-resistant Staphylococcus aureus (MRSA)-screen latex agglutination test for detection of MRSA of animal origin. J. Clin. Microbiol. 42:2780-2782.

Lee J.H. 2003. Methicillin (oxacillin)-resistant Staphylococcus aureus 
strains isolated from major food animals and their potential transmission to humans. Appl. Environ. Microbiol. 69:6489-6494.

Linehan D., Etienne J. \& Sheehan D. 2003. Relationship between haemolytic and sphingomyelinase activities in a partially purified $\beta$ like toxin from Staphylococcus schleiferi. FEMS Immunology and medical Microbiology 36(1/2):95-102.

Moon J.S., Lee A.R., Kang H.M., Lee E.S., Kim M.N., Paik Y.H., Park Y.H., Joo Y.S. \& Koo H.S. 2007. Phenotypic and genetic antibiogram of methicillin-resistant Staphylococci isolated from bovine mastitis in Korea. J. Dairy Sci. 90:1176-1185.

O’Mahony R., Abbott Y., Leonard F.C., Markey B.K., Quinn P.J., Pollock P.J., Fanning S. \& Rossney A.S. 2005. Methicillin resistant Staphylococcus aureus (MRSA) isolated from animals and veterinary personnel in Ireland. Vet. Microbiol. 30:285-296.

Pak S.I., Han H.R. \& Shimizu A. 1999. Characterization of methicillinresistant Staphylococcus aureus isolated from dogs in Korea. J. Vet. Med. Sci. 61:1013-1018.

Palma M., Haggar A. \& Flock J. 1999. Adherence of Staphylococcus aureus is enhanced by an endogenous secreted protein with broad binding activity. J. Bacteriol. 181(9):2840-2845.

Park P.W., Foster T.J., Nishi E., Duncan S.J., Klagsbrun M. \& Chen Y. 2004. Activation of Syndecan-1 Ectodomain Shedding by Staphylococcus aureus $\alpha$-Toxin and $\beta$-Toxin. J. Biol. Chem. 279(1):251-258.

Reinoso E., Bettera S., Frigerio C., Direnzo M., Calzolari A. \& Bogni C. 2001. RAPD-PCR analysis of Staphylococcus aureus strains isolated from bovine and human hosts. Microbiol. Res. 159:245-255.

Reinoso E.B. 2004. Análisis epidemiológico y molecular de cepas de Staphylococcus aureus de distintos orígenes. Tese de Doutorado, Instituto de Microbiologia, Universidad Nacional de Rio Cuarto, Argentina. 199p.

Reis S.R., Silva N. \& Brescia M.V. 2003. Antibioticoterapia para controle da mastite subclínica de vacas em lactação. Arq. Bras. Med. Vet. Zootec., 55:651-658.

Rich M. \& Roberts L. 2004. Methicillin-resistant Staphylococcus aureus isolates from companion animals. Vet. Rec. 154(10):310.
Salasia S.I.O., Khusnan Z., Lämmler C. \& Zschock M. 2004. Comparative studies on pheno- and genotypic properties of Staphylococcus aureus isolated from bovine subclinical mastitis in central Java in Indonésia and Hessen in Germany. J. Vet. Sci. 5(2):103-109.

Schocken-Iturrino R.P., Nader Filho A., Avila F.A. \& Almeida G.P.C. 1996. Susceptibility of coagulase-positive Staphylococcus isolated from bovine subclinical mastitis to antibacterial agents. Ars Vet. 12:5763.

Senna M.C., Struelens M.J., Deplano A., Se Ryck R., Hauser P.M., Petignat C. \& Francioli P. 2002. Epidemiological validation of pulsedfield gel electrophoresis patterns for methicillin-resistant Staphylococcus aureus. J. Clin. Microbiol., 39:3442-3445.

Shopsin B., Gomez M., Waddington M., Riehman M. \& Kreiswirth B.N. 2000. Use of coagulase gene ( $\mathrm{COa}$ ) repeat region nucleotide sequences for typing of methicillin-resistant Staphylococcus aureus strains. J. Clin. Microbiol. 38(9):3453-3456.

Steinhuber A.C., Goerke M.G., Bayer G. \& Döring C. 2003. Molecular architecture of the regulatory locus sae of Staphylococcus aureus and its impact on the expression of virulence factors. J. Bacteriol. 185:62786286.

Straub J.A., Hertel C. \& Hammes W.P. 1999. A 23S RNAr-targeted polymerase chain reaction-based system for detection of Staphylococcus aureus in meat started cultures and dairy products. J. Food Prot. 62:1150-1156.

Weese J.S., Rousseau J., Traub-Daratz J.L., Willey B.M., McGreer A.J. \& Low D.E. 2005. Community-associated methicillin-resistant Staphylococcus aureus in horses and humans who work with horses. J. Am. Vet. Med. Assoc. 226:580-583.

World Health Organization (WHO). 2002. Surveillance standards for antimicrobial resistance: Guidelines for assessment teams. WHO/CDS/ CSR/ISR/2002.2.

Zafalon L.F., Nader Filho A., Oliveira J.V. \& Resende F.D. 2007. Mastite subclínica causada por Staphylococcus aureus: custo-benefício da antibioticoterapia de vacas em lactação. Arq. Bras. Med. Vet. Zootec. 59(3):577-585. 